\title{
Adverse Event Associated with Serious Medical Event
}

National Cancer Institute

\section{Source}

National Cancer Institute. Adverse Event Associated with Serious Medical Event. NCI

Thesaurus. Code C83053.

An indication or description of an adverse event associated with a critical medical event. 